Journal of British Studies 60 (April 2021): 285-309. doi:10.1017/jbr.2020.242

(C) The North American Conference on British Studies, 2021. This is an Open Access article, distributed under the terms of the Creative Commons Attribution licence (http://creativecommons.org/licenses/by/4.0/), which permits unrestricted re-use, distribution, and reproduction in any medium, provided the original work is properly cited.

\title{
Poor Law Institutions through Working-Class Eyes: Autobiography, Emotion, and Family Context, 1834-1914
}

\section{Alannab Tomkins}

\begin{abstract}
Histories of the English workhouse and its satellite institutions have concentrated on legal change, institutional administration, and moments of shock or scandal, generally without considering the place of these institutions, established through the Poor Law Amendment Act of 1834, in the emotional life course of poor inmates. This article uses working-class autobiographies to examine the register of emotional responses to workhouses and associated Poor Law institutions, and the range of narrative voices open to authors who recalled institutional residence. It also gives close attention to two lengthy narratives of workhouse district schools and highlights their significance in comparison to the authors' family backgrounds and the representation of each writer in the wider historical record. It suggests that a new affective chronology of the workhouse is needed to accommodate room for disparity between the aspiration of systematic poor relief and the reality of individual experience within local interpretations of the law.
\end{abstract}

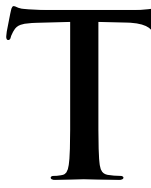

he autobiography of Ada Bennett (b. 1901) offers readers a disconcerting description of Poor Law institutions, because it departs from typical expectations for such a memoir: Bennett expresses fondness for a workhouse and its affiliated district school. Her attitude was at least partly a consequence of the domestic deprivation she endured beyond these institutional walls. In contrast to hunger at home, she enjoyed the material comforts that entry to a workhouse and its school could offer. Her father was a painter and decorator; a widower, he took his children home when he was in work but otherwise lodged them in the Southwark workhouse. From the workhouse, they were periodically transferred to the Central London District School at Hanwell. Bennett was accompanied on these institutional sojourns by a sibling, an older brother, and although the rules of the workhouse and school required that they be separated from one another, Bennett remembered her school days with evident affection. Her memoirs cannot be suspected of whitewashing a difficult past by claiming an unalloyed depiction of happiness; for example, she contrasted her enjoyment at being given sixpence each at New Year, to spend on sweets when out for walks, with the discipline enacted on girls who wet their

\footnotetext{
Alannah Tomkins is a professor of history at Keele University. She is substantially indebted to the colleagues who read and listened to the different drafts of this article as it evolved, including the anonymous readers for the Journal of British Studies, and most particularly professors David Vincent, Jonathan Reinarz, and Penny Summerfield, whom she thanks for their encouragement, which kept her going. Please direct any correspondence to a.e.tomkins@keele.ac.uk.
} 
beds. Her brother even tried running away. Nonetheless, she also remarked that, as an adult, her brother "was very grateful for the way the school had looked after us." The Bennett children left Hanwell for the last time when their father remarried; Bennett concluded her reminiscences at this point in her history with the faintly ominous words, "and that is another story." 2 Arguably, the workhouse and school provided Bennett and her brother with structure and creature comforts during an otherwise uncertain childhood, in contrast to their experience of a perhaps antipathetic stepmother. At the same time, Bennett's autobiography offers us an unusual view of the place of these interventions established by the Poor Law Amendment Act of 1834 (widely known at the New Poor Law) in the life course and the emotional memory of their clientele.

The post-1834 workhouse and its satellite institutions, including district schools, cottage homes, and infirmaries, have a long and detailed historiography. The earliest retrospectives offered by those commenting on these interventions as a contemporaneous system attempted a broad-brush policy view, while subsequent scholarly work has increasingly focused on place, period, or extraordinary events that spurred public reaction or government response (or both) ${ }^{3}$ Latterly, this specificity has included a greater representation for the poor themselves. Letters written by or on behalf of paupers or their families offer hard evidence of perspectives among people in the ambit of attention from the New Poor Law. ${ }^{4}$ Some of these works cover an aspect of institutional life over an extended period; others may illuminate an establishment at a moment of particular interest, crisis, or scandal. They are less able to comment on the importance of institutional living for individual inmates in the context of their broader life course, since even persons with repeat admissions to successive workhouses, or to other Poor Law institutions, overwhelmingly left their pre- and postresidence life at the door. If they address the place of the workhouse in the affective landscape of the poor, they typically do so by reference to well-worn assumptions, such as that the poor found the workhouse so oppressive and repellent that they avoided it at all costs. ${ }^{5}$

Autobiographies add a distinctive dimension to the history of Poor Law institutions, enabling us to expand our appreciation of the potential for trauma that

\footnotetext{
$1{ }^{*}$ A. Bennett, "In the Workhouse," The Times of Our Lives (London, 1983), 85-87. All thirteen of the core texts used in my research are referenced in the footnotes to this article, identified (as here) by an asterisk preceding the first full reference.

${ }^{2}$ Bennett, "In the Workhouse," 87.

${ }^{3}$ For the two ends of this historiographical spectrum, see Sidney and Beatrice Webb, English Poor Law History: The Last Hundred Years (London, 1929); Samantha A. Shave, Pauper Policies: Poor Law Practice in England, 1780-1850 (Manchester, 2017).

${ }^{4}$ See, for example, Peter Jones and Steven King, "Voices from the Far North: Pauper Letters and the Provision of Welfare in Sutherland, 1845-1900," Journal of British Studies 55, no. 1 (2016): 76-98. See also the project In Their Own Write (funded by the Arts and Humanities Research Council), which is concerned with pauper writings and agency after 1834: "About," In Their Own Write: The Lives and Letters of the Poor 1834-c.1900, accessed 1 July 2019, https://intheirownwriteblog.com/about/.

${ }^{5}$ Jane Humphries, "Care and Cruelty in the Workhouse: Children's Experiences of Residential Poor Relief in Eighteenth and Nineteenth Century England," in Childhood and Child Labour in Industrial England: Diversity and Agency, 1750-1914, ed. Katrina Honeyman and Nigel Goose (Farnham, 2013), 115-34. Humphries ascribes John Munday's avoidance of the workhouse to aversion or loathing, when his own account is more circumspect. See Reginald Blunt, "Early Victorian Recollections: John Munday's Memories," in Red Anchor Pieces (London, 1928), 99-121.
} 
inmates suffered but also to understand the importance of other emotions, including nostalgia and qualifiers of feeling such as quasi-familial identification. In this article I use autobiographical accounts of Poor Law institutions to speak to the writers' life courses and to the emotions they ascribed to historic experiences. I survey the scope, depth, and emphases of life narratives that make significant mention of workhouses, schools, infirmaries, and cottage homes in the period up to 1913 and consider the methodological problems they raise. I focus on the narrative typologies that are evident in different texts and on the range of meanings invested in them. ${ }^{6}$ I then turn to two lengthier accounts for closer scrutiny, interleaving the narratives with individual and family histories retrievable from census and other records. Here the inherently patchy, accidental, contingent aspects of autobiographies can be understood and turned to good account. Institutions were inhabited and run by people with a very broad variety of expectations, practices, and responses, and so the characters of the autobiographers and of the people they met can be investigated to weigh the impact of institutional systems against that of individuality, personality, and feeling. The experience of children or adolescents and their family context is given priority in this final section, analyzing depictions of London's workhouse district schools and their subsequent affective influence over a life.

\section{EMOTIONS, INSTITUTIONS, AND FAMILIES}

Working-class autobiographies are the only sources that can speak to both the practical and the emotional impact of institutional residence on a person's life course. When the history of poverty meets the history of the emotions, it is necessary to ask what constituted acceptable emotional expression among those remembering assistance through interventions such as those established through the New Poor Law. Admittedly, histories of the emotions have not always framed questions in quite this way. Starting with anger, there is now an established literature that addresses specific emotions or interrogates the relationship between the words used as descriptors and the bodily feelings they represent. ${ }^{7}$ However, I work from a different tradition, one that starts by problematizing a period or context. For example, in writing about the Middle Ages, Barbara Rosenwein suggests that historical actors inhabited "emotional communities" contiguous with social communities. Her focus is on systems of feeling: as people moved between communities, they adjusted both their judgments of advantage or detriment and their concomitant displays of emotion. ${ }^{8}$ In this way, communities shaped emotions differently, but in accordance with "feeling rules" conferred by context and experience." William

\footnotetext{
${ }^{6}$ For narrative strategies in working-class autobiographies per se, see David Vincent, "Working-Class Autobiography in the Nineteenth Century," in Adam Smyth, ed., A History of English Autobiography (Cambridge, 2016), 165-78.

7 See Carol Zisowitz Stearns and Peter K. Stearns, Anger: The Struggle for Emotional Control in America's History (Chicago, 1986); Claire Langhammer, The English in Love: The Intimate Story of an Emotional Revolution (Oxford, 2013); Hera Cook, "Emotion, Bodies, Sexuality, and Sex Education in Edwardian England," Historical Journal 55, no. 2 (2012): 475-95.

${ }^{8}$ Barbara Rosenwein, Emotional Communities in the Early Middle Ages (Ithaca, 2006), 2.

9 Arlie Russell Hochschild, The Managed Heart: Commercialization of Human Feeling (Berkley, 2012), 15.
} 
Reddy points additionally to the fact that "emotion and emotional expression interact in a dynamic way": the act of describing an emotion can distil or complicate the experience of feeling giving rise to "emotional regimes." 10 The mutability of regimes altered what could be felt.

This combination of fluidity and constraint implies that in relation to inmates of Poor Law institutions, we should identify the norms and extremes of emotional expression to understand more about the emotional climate of poverty and welfare from 1834, when these institutions were established by the New Poor Law, onward. Was there room for flexibility, or were emotional statements the result of "overlearned habit"? 11 This sort of perspective enables secondary questions about the function of remembered emotion in rendering autobiographies coherent and persuasive accounts of a life. Emotional style may well be "a marker of class identity," but how far did a working-class identity determine discrete responses, or confessed responses, to the interventions of the New Poor Law? ${ }^{12}$ Or was one's emotional attitude toward the workhouse a reflection instead of one's increased distance from it in later life and subsequent incorporation of sentiments from beyond the working class? Access to varied emotional styles probably improved in this era: Cas Wouters points to the erosion of formality and the blurring of class lines in written evidence of emotion management drawn from the first half of the twentieth century. Autobiographers would have been permitted by these means "to draw dividing lines on the basis of certain kinds of behavior, not certain kinds of people" and so to have protested the validity of their own experience and demeanor, including in the context of exposure to the Poor Law. ${ }^{13}$ Did individualization influence these writers and mean they gained access to a "second draft" of their emotional responses? ${ }^{14}$ Or did it render their task more difficult if they felt invited or obliged to inhabit more than one community or regime? Fortunately, the subset of autobiographies that treat life in Poor Law institutions, unlike those in other surveys, are relatively well stocked with evidence of emotion with which the historian may work. ${ }^{15}$

An expression of experience and emotion may be partial or fulsome, even-tempered or impassioned, but for it to qualify fully as an autobiographical account, its author will have invoked context, and one form of context is both prominent and pervasive. Family background is important to most autobiographers and sometimes occupies a dominant portion early in the narrative. ${ }^{16}$ Writers typically try to situate

${ }^{10}$ William M. Reddy, The Navigation of Feeling: A Framework for the History of Emotions (Cambridge, 2001), xii, 126, and chap. 4.

${ }^{11}$ Alice M. Isen and Gregory Andrade Diamond, "Affect and Automaticity," in Unintended Thought, ed. James S. Uleman and John A. Bargh (New York, 1989), 124-53, at 144.

12 Susan J. Matt, "Current Emotion Research in History: or, Doing History from the Inside Out," Emotion Review 3, no. 1 (2011): 117-24, at 121.

${ }^{13}$ Cas Wouters, "Etiquette Books and Emotion Management in the 20th Century. Part 1: The Integration of Social Classes," Journal of Social History (1995): 107-24, at 113.

${ }^{14}$ Rosenwein, Emotional Communities, 19; Michael Rustin, "Reflections on the Biographical Turn in Social Science," in The Turn to Biographical Methods in Social Science, ed. Joanna Bornat, Prue Chamberlayne, and Tom Wengraf (London, 2000), 33-52.

15 Julie-Marie Strange, Fatherhood and the British Working Class, 1865-1914 (Cambridge, 2015), 14-15.

${ }^{16}$ Demonstrated in Megan Doolittle, "Fatherhood and Family Shame: Masculinity, Welfare and the Workhouse in Late Nineteenth-Century England," in The Politics of Domestic Authority in Britain since 1800, ed. Lucy Delap, Ben Griffin, and Abigail Wills (Basingstoke, 2009), 84-108; Strange, Fatherhood, $14-15$. 
themselves in a family context, particularly in birth order and in relationships with parents and siblings. ${ }^{17}$ They are much more attentive to interactions with their mother and father than to their experience as parents to their own children. ${ }^{18}$ This feature of autobiographical writing provides connections that do not usually arise among primary sources for institutions where admission took place in childhood or adolescence. Authors reference parental failings and/or the breakup of the birth household as the cause of institutional experience, and the behavior of staff who shared a diluted loco parentis role can assume great significance in the afterlives of former inmates. This means that the place of any one institution in a written life is given direct counterweight by the affective significance-positive or negative- of family. This emphasis on family is not an attempt on my part to hark back to a form of social history that predates the "cultural turn." Instead, and in line with Michael Roper's injunction for gender history to avoid the lifelessness that ensues when "signification is the start and end point of study," I aim to amalgamate literary representation with the material of genealogy. 19

\section{WORKING-CLASS AUTOBIOGRAPHIES: SURVIVING NARRATIVES}

Working-class autobiographies have taken an acknowledged place in the roster of social and economic historians' sources, particularly when used in large numbers to consider expansive topics like industrialization. ${ }^{20}$ Whether taken as the source of factual material or as the pathways to subjective truths, they have won a "claim to embeddedness within real experience." 21 They can also be used selectively to address issues less extensively represented in the genre. ${ }^{22}$ While Poor Law institutions are often referenced in working-class autobiographies, they are much more frequently referenced by external commentators than by residents. Among those authors who incorporate institutional experience into their narratives, an even smaller group reflects on a single institution as a permanent inmate with a legal settlement, ${ }^{23}$ as opposed to multiple institutions as a vagrant inmate. Just twenty-five

\footnotetext{
${ }^{17}$ More than four hundred autobiographies comment on motherhood in Victorian Britain. See Emma Griffin, "The Emotions of Motherhood: Love, Culture, and Poverty in Victorian Britain," American Historical Review 123, no. 1 (2018): 60-85, at 65.

${ }^{18}$ See, for example, the memoirs of John Lincoln, paraphrased in Emma Griffin, Liberty's Dawn: A People's History of the Industrial Revolution (New Haven, 2013), 3-4.

${ }^{19}$ Michael Roper, "Slipping out of View: Subjectivity and Emotion in Gender History," History Workshop Journal 59, no. 1 (2005): 57-72, at 62.

${ }^{20}$ Variously, David Vincent, Bread, Knowledge, Freedom: A Study of Nineteenth-Century Working Class Autobiography (London, 1981); John Burnett, Idle Hands: The Experience of Unemployment, 1790-1990 (London, 1994); Jane Humphries, Childhood and Child Labour in the British Industrial Revolution (Cambridge, 2010); Emma Griffin, Liberty's Dawn.

${ }_{21}$ Penny Summerfield, Histories of the Self: Personal Narratives and Historical Practice (Abingdon, 2018), 78-79; Mary Fulbrook and Ulinka Rublack, "In Relation: The 'Social Self' and Eco-documents," German History 28, no. 3 (2010): 263-72, at 267.

${ }^{22}$ See, for example, Julie-Marie Strange, "Fathers at Home: Life-Writing and Late Victorian and Edwardian Plebeian Domestic Masculinities," Gender and History 27, no. 3 (2015): 703-17; Humphries, "Care and Cruelty in the Workhouse."

${ }^{23}$ The term permanent inmate differentiates these writers from those who lived a vagrant lifestyle and instead saw the workhouse only from the perspective of the temporary vagrants' wards. Legal settlement refers to the legal provisions that allowed Poor Law unions to differentiate between paupers who belonged
} 
autobiographies of the 2,444 catalogued by Burnett, Vincent, and Mayall provide accounts of post-1834 workhouses or affiliated institutions from the perspective of a resident inmate who was not solely admitted to a vagrancy ward up to 1914. Of these, only eleven treat the relevant period of writers' lives at length or in detail. ${ }^{24}$ This means that, the many glancing references to workhouses and satellite institutions aside, the extended commentary from within drawn upon here is thus confined to these eleven texts, augmented by two further narratives emerging since the late 1980s. ${ }^{25}$ The substantive analysis I provide below is based on this core subset of thirteen texts.

More-and more representative-accounts may yet be found. As Vincent observes, "the tail of printed ephemera and unpublished reminiscences has no ending," and approximately a fifth of the citations in Emma Griffin's research on working-class autobiographies are in addition to those calendared by Burnett, Mayall, and Vincent. ${ }^{26}$ Until more specifically Poor Law memoirs are discovered, though, the thirteen narratives that I reference here display some noteworthy emphases. They focus on institutions in the south of England, with London predominating, while individual outliers treat workhouses in Bedford, Birmingham, Staffordshire, and St. Asaph in Wales. Furthermore, the majority of these works were written by men, with just three by women, and only one among the core texts treats institutional memories at length.

These accounts are read here not for fact but for perspective. The most prominent consistency among them is that they were chiefly composed when their authors' contact with the interventions of the New Poor Law was at least a decade, and more commonly multiple decades, in the past. They were therefore the product of conscious self-fashioning with the scope for a good deal of hindsight, reflection, and "residues of earlier versions of selfhood." 27 This distant perspective is given a further refinement in that most of the authors were under twenty when they experienced Poor Law institutions. It is noteworthy that just one of the core writers surveyed here mentioned receipt of welfare in later life. ${ }^{28}$

There is thus a need to consider the likely impact of childhood on memory making. If we acknowledge the use of modern psychoanalytical techniques in the historical study of childhood memories, some aspects of current understanding are pertinent. It is possible to detect a tendency among impoverished children, for example, to make the best of things and become attached to people and places, no matter how challenging the circumstances, and this can be witnessed among biographers with

to them and those who belonged elsewhere. The latter could be forcibly removed to a different location and the cost of their relief transferred to another authority.

${ }^{24}$ John Burnett, David Vincent, and David Mayall, eds., The Autobiography of the Working Class: An Annotated Critical Bibliography, 3 vols. (Brighton, 1987).

${ }^{2}{ }^{*}$ W. H. R. [William Hew Ross], given in E. C. Tufnell, "Education of Pauper Children," Parliamentary Papers, Third Annual Report of the Local Government Board 1873-4 (London, 1874), 248-59; *Joseph Bell, "Chapters from the Autobiography of a Village Lad Showing the Hardships and Superstitions of Village Life in England from 1846 to 1858 [. . . ]," typescript, 1926, Bedfordshire Archives and Records Service, Bedford.

${ }^{26}$ Vincent, "Working Class Autobiography," 167; Griffin, Liberty's Dawn, 248.

${ }^{27}$ Fulbrook and Rublack, "In Relation," 267.

${ }^{28}$ See below, note 67 . 
experience of the New Poor Law. 29 "Emma Smith" describes a childhood of parental abandonment, workhouse residence, sexual abuse, and extreme material deprivation, yet even she reflects on happy moments; she eventually became strongly attached to a nurse in the penitentiary she entered at age twelve. ${ }^{30}$ For authors consciously or unconsciously shaping their memories for committal to paper, there was scope for childhood memories of institutional life to be set in a positive mold in a way that identical exposure at a more mature age would qualify or reject.

This is useful to bear in mind, but for the purposes of this article, our awareness of authors' choices in framing childhood memories is teamed with additional twentiethcentury research that is informed by the work of William Reddy: the telling and retelling of emotion may consolidate memories of feeling in ways that confer authenticity on first-person recall of childhood by adults, whether or not they were formed in situations of stress. Neil Sutherland argues that memories of repeated events or circumstances generate "scripts" of generalized memory. ${ }^{31}$ Childhood's scripts, he maintains, emanate from highly structured situations-structured by the demands of domestic life such as "washday," by the timetables that governed work or education, or by features imposed by the generational stage of the child. Furthermore, children share experiences with others living alongside them (family, friends, and teachers or holders of official roles); all of these people have the capacity to reinforce their stories by telling them to each other. As the child who experiences becomes the adult who remembers, the stories they tell emerge from the general patterns of scripted memories. ${ }^{32}$ By these means, the ascription of emotion becomes fuller rather than more tenuous.

\section{DYNAMIC POLICIES AND STATIC PERCEPTIONS}

In using autobiographies to write about the New Poor Law of 1834 onward, I had to run a number of gauntlets, not least a chronological one. Historians of the Poor Law rightly see the trajectory of welfare historiography from 1834 on as shifting significantly, from the founding of the law in the 1830s, through early trials and scandals to establish acceptable policy, to the crusade against out-relief, and ultimately to the political changes wrought by the introduction of working-class Guardians and the Liberal welfare reforms of 1906-1909. In the existing literature, the workhouse of 1914 and its associated residential establishments is an entirely different institution from its predecessor in 1834. Furthermore, since all but one of the core autobiographers wrote in old age about youth, no authors were writing in the earliest decades of the New Poor Law, and many did not write or publish until the twentieth century. Their recollections were recorded or made public in decades when quite different welfare policies from the ones they describe were in place.

\footnotetext{
${ }^{29}$ John Bowlby, "The Nature of the Child's Tie to His Mother," International Journal of Psychoanalysis 39, no. 5 (1958): 350-71.

${ }^{30}$ A. L. Rowse, ed., A Cornish Waif's Story (London, 1954). Smith's autobiography is not one of the core thirteen referenced here, because her coverage of the workhouse proper (as opposed to charitable institutions) is very brief.

${ }^{31}$ Neil Sutherland, Growing Up: Childhood in English Canada from the Great War to the Age of Television (Toronto, 1997), 9-12.

${ }^{32}$ Sutherland, Growing Up, 8-12.
} 
In contrast to this historical literature, periodization is largely missing from autobiographical writings. The workhouse, district school, or infirmary might as well have been eternal and unchanging as far as the authors were concerned. Undoubtedly, this perspective partly arises from autobiographers' relatively short residences in an institution that survived for nearly a century: none of the writers surveyed here reported remaining in Poor Law accommodation for more than thirteen years, and most stays were much shorter. It may also be a feature of the authors' youth at the time of admission that they experienced what was in front of them in a quotidian way; they had no occasion to gain a broader view of an establishment under the control of a central authority and answerable to Parliament. ${ }^{33}$ They knew a specific master, matron, nurse, teacher, doctor, or porter and were unaware of the generalized qualities desirable for these posts or the ways that the behavior of those holding the posts was regulated. Similarly, they may have been little inclined in retrospect to consider these adults as employees, often with inadequate training, support, and oversight of their role. ${ }^{34}$ The fixity of workhouse and Poor Law experiences could certainly be the view among the working classes who did not become inmates. As one writer put it, from the perspective of an observer rather than a resident, "The Poor Law, as far as I can gather, had not changed much, except for the worse, since it was begun by Henry the Eighth or the first Elizabeth until it was finished in 1949." $" 35$

Autobiographers' lack of attention to changing Poor Law practices may also be a testament to the complex relationship between ideological change, policy shift, implementation of change, and maturation of process. Samantha Shave's recent work putting policy process at the heart of developments in Poor Law policy points to the slow, piecemeal, haphazard, or unintended consequences of administrative change, and the parallel, sometimes disconnected activities of Poor Law employees, which were undertaken without reference to official guidance. ${ }^{36}$ Autobiographies disrupt the coherence of institutions in the same way that Shave's research disrupts the coherence of policy. The reformed Poor Law of 1834 may have been designed to suppress local variation and replace it with systematic and accountable uniformity, and institutions have subsequently been perceived as possessing the power to structure social relations decisively to inmates' detriment. ${ }^{37}$ Writers' individual experiences, however, are structured by neither system nor considerations of abstract power but by the stories they have heard about institutions and by their unique exposure to them.

And the stories were powerful. Engels saw this clearly when he distinguished between the humane provision for deserving poverty that technically underlay the Poor Laws per se from 1601 and the intention or spirit of harsh pragmatism of

${ }^{33}$ Harry Price was the exception to this generalization. A resident of the workhouse in Warminster before, during, and after 1834, he saw the effects of administrative change. *Harry Price, "My Diary," Islington Local History Centre (MS, 86 pp.), 7-22.

${ }^{34}$ John Adams, "The Last Years of the Workhouse," in Oral History, Health and Welfare, ed. Joanna Bornat, Robert Perks, Paul Thompson, and Jan Walmsley (London, 2000), 97-118, at 105.

${ }^{35}$ Andie Clerk, Arab: A Liverpool Street Kid Remembers (1971), 33. In fact, the Poor Law "finished" in 1948.

${ }^{36}$ Shave, Pauper Policies, 248-67

${ }^{37}$ Michel Foucault, Discipline and Punish: The Birth of the Prison (New York, 1975). 
the New Poor Law of 1834 to criminalize poverty and stigmatize the dependent poor: workhouse paupers were regarded as "objects of disgust and repulsion." 38 That this revulsion was felt keenly by some or most among the working classes has become a shibboleth of the popular perception of workhouses. ${ }^{39}$ An act of writing that took place in the early or mid-twentieth century could also draw on updated models for emotional understanding of childhood experience, but new models did not necessarily swamp old ones: in common with works reflecting on the First World War, "post-war use in memoirs of concepts such as 'unconscious,' 'repression' and 'sublimation' was always mediated by older languages of the self."40

Therefore we need to recognize the likely impacts of both chronological distance and trauma on the memory of workhouse inhabitants, particularly when combined with the presence of other, apparently confirmatory cultural narratives- "not only the narrative offered, but also the meanings invested in it."4l Recent work on war veterans and their memoirs suggests that people undergoing traumatic events later find that their recollections become uncannily similar to pervasive, popular, but imagined accounts. This "assimilation to the dominant narrative" introduces the possibility that there was contextual pressure for workhouse memoirists to adhere to or align with the pervasive image of Poor Law institutions even when their own experience of day-to-day life in that institution was not predominantly characterized by hunger and physical violence. ${ }^{42}$ Like the survivors of twentieth-century war, inmates of Poor Law institutions might have been writing what their readers wanted or expected to encounter: a familiar, albeit shocking account eliciting a sympathetic, outraged, and relatively unquestioning response. ${ }^{43}$

So while the Poor Law has been systematically demythologized by local studies and historiographical specificity, most participants lived through only a small portion of their institution's history and potentially fell prey to the myth. On the evidence of this array of narratives covering institutional residence, memoirists certainly acknowledged other stories, but they also expressed their recollections in distinctive, individual voices that did not consistently cohere to a single generalizing schema.

\section{NARRATIVE DIVERSITY}

Autobiographers describing institutional life confronted a paradox: they were attempting to characterize and shape their experience, but for a period of reduced or absent personal agency. Whatever they felt about being an inmate, they were limited in what they could do as a lone actor to alter their account of subjection to administrative structures or personnel. At the same time, they were generally

\footnotetext{
${ }^{38}$ Friedrich Engels, The Condition of the Working Class in England (New York, 1887), 192.

${ }^{39}$ M. A. Crowther, The Workhouse System, 1834-1929: The History of an English Social Institution (Athens, GA, 1981), 223; Simon Fowler, The Workhouse: The People, the Places, the Life behind Doors (Kew, 2007), 82-83, 118-19, 128-29, 175, 226.

40 Roper, "Slipping out of View," 66.

${ }^{41}$ Penny Summerfield, "Culture and Composure: Creating Narratives of the Gendered Self in Oral History Interviews," Cultural and Social History 1, no. 1 (2004): 65-93, at 67.

${ }^{42}$ Alistair Thomson, ANZAC Memories: Living with the Legend (Melbourne, 1994), 215.

${ }^{43}$ Lucy Robinson, "Soldiers' Stories of the Falklands War: Recapturing Trauma in Memory," Contemporary British History 25, no. 4 (2011): 569-89, at 570.
} 
aware of similar or parallel lives in the public domain. A small roster of well-known working-class autobiographical texts in fairly wide circulation up to the 1960s comprised merely the most visible among a larger pool of local memoirs produced quietly, informally, or in small runs by provincial presses. ${ }^{44}$ Parallel lives were being rendered in compelling ways in fiction. ${ }^{45}$ By these means, the scope of expression expanded drastically from the earliest start point of relevant texts (the implementation of the reformed Poor Law in 1834) to the latest feasible point of writing (after the last person who remembered workhouse life had died). The voice or tone assumed by authors illustrates the way they managed their feelings, or "emotional economy" in the context of diminished agency. ${ }^{46}$

I confess that on beginning this research I had Oliver Twist firmly in mind. As Dickens's novel was published in the early days of the New Poor Law, readers (or others aware of its early chapters) could have relied on a template for the child-victim role in which inmates were starved and the likely result of workhouse admission for both children and adults was death, overseen by Mr. and Mrs. Bumble. The boy who asked for more and the context of his request "remained the standard image [of the workhouse child] for the Victorian age" and is familiar even among people who have never read the book or seen filmed adaptations. ${ }^{47}$ Jonathan Rose credits Dickens with a "dominating presence" in working-class memoirs beyond those concerned with the Poor Law, wherever writers concluded that the novelist was "the man who got it right." 48

Thus it is unsurprising to find that this biographical facsimile contributed to the repertoire of narratives available to life writers. Frank Stone (pseudonym Frank Steel) was the most explicit in this respect, titling one of his chapters "Breakfast with Bumble" and citing multiple other points of comparison. ${ }^{49}$ Henry Price regarded the workhouse diet shortly after 1834 as "semistarvation" and thought himself "Oliver Twist like" in being apprenticed from the workhouse to a carpenter. ${ }^{50}$ Five more of the core thirteen texts reflect the Dickensian pattern, whereby institutional living gives rise to itemized depictions of deprivation or physical and psychological violence (albeit without further reference to Twist or Dickens specifically). Charlie Chaplin and Fred Copeman commented on their personal experience of isolation and shame. ${ }^{51}$ Others, like Henry Morton Stanley in St. Asaph, remembered appalling regimes of corporal punishment. ${ }^{52}$ William Hew Ross recalled being beaten so regularly that his fear induced persistent stammering, and he believed

\footnotetext{
44 Vincent, "Working-Class Autobiography," 166-67.

${ }^{45}$ Regenia Gagnier, Subjectivities: A History of Self-Representation in Britain, 1832-1920 (Oxford, 1991), 145 .

${ }^{46}$ Joan B. Landes, Visualizing the Nation: Gender, Representation and Revolution in Eighteenth-Century France (Ithaca, 2001); Roper, "Slipping out of View," 58.

${ }^{47}$ Lydia Murdoch, Imagined Orphans: Poor Families, Child Welfare, and Contested Citizenship in London (New Brunswick, 2006), 1; Ruth Richardson, Dickens and the Workhouse: Oliver Twist and the London Poor (Oxford, 2012), 13.

${ }^{48}$ Jonathan Rose, The Intellectual Life of the British Working Classes (New Haven, 2001), 111-12.

$49{ }^{*}$ Frank Steel, Ditcher's Row: A Tale of the Older Charity (London, 1939).

${ }^{50}$ Price, "My Diary," 13, 16.

$51{ }^{*}$ Charlie Chaplin, My Autobiography (New York, 1964); *Fred Copeman, Reason in Revolt (London, 1948).

52 *Dorothy Stanley, ed., Autobiography of Sir Henry Morton Stanley (Boston, 1909).
} 
that one unprovoked blow to the head was the origin of his periodic ear pain and dizziness into adulthood. ${ }^{53}$ An influential example in this vein was the autobiography of Charles Shaw, admitted to the Wolstanton and Burlsem Union workhouse at Chell in North Staffordshire when he was around age ten. ${ }^{54}$ His four or five weeks in the workhouse remained a cause of anger sixty years later, when he reflected on the inedible diet-on his description, no one would have asked for more under any inducement-and the fear of being housed in the same dormitories as more unruly boys without adult oversight. His account has subsequently been used to inform literary fiction and historical scholarship. ${ }^{55}$

What I had not anticipated was the variety of emotions attached to institutional memories by authors who pulled away from the famously negative exemplar, from a pointed separation from Oliver Twist to an array of different narratives. Samuel Shaw openly repudiated a negative reading of institutional life to insist on his contentment in the workhouse and its various departments. Born in 1884, he became in adult life a "fervent anti-socialist," opposing trades unions and engaging in public speaking for the Conservative Party; this outlook no doubt influenced his published recollection of welfare institutions and his determination to reject the Dickensian example. ${ }^{56}$ When he was about eight years old, he and his sister entered the Erdington workhouse. They progressed to a cottage home and to the Birmingham workhouse infirmary before being discharged approximately two years later. Shaw concluded that he "must have been fairly well fed" in direct contradiction of the Oliver Twist model, since he referenced workhouse descriptions by "writers of immortal fame" (that is, Dickens) but did not recall himself asking for more. He was particularly upbeat about the infirmary. He spent months in these "pleasant surroundings" - a phrase clearly not meant to be read ironically-and maintained he left "restored to health and vigour... with happy memories of the kindness showered on us." 57

Beyond the clearest instances of Dickensian influence (Steel, Price, and Sam Shaw), the remaining core autobiographies offer a variegated emotional landscape for institutional residency. Broadly, the authors wrote improvement or self-improvement dramas depicting their entry to a Poor Law institution as the nadir from which they returned, their emotional investment in the associated memories illustrating their changed or changing fortunes. Ada Bennett, quoted in the introduction, was one such; Edward Balne, a contemporary of Bennett's at the same institution, had similarly positive views. ${ }^{58}$ William Hew Ross blurs the line between a potentially Dickensian-model workhouse and personal self-improvement when he valorizes the opportunity offered him by the workhouse district school; however, his autobiography arises because he was asked by assistant Poor Law commissioner

${ }^{53}$ Ross, in Tufnell, "Education of Pauper Children," 253.

$54{ }^{*}$ Charles Shaw, When I Was a Child (Firle, 1980).

${ }^{55}$ For example, Arnold Bennett, Clayhanger (London, 1910); Stephen P. Walker, "Accounting, Paper Shadows and the Stigmatised Poor," Accounting, Organisations and Society 33, no. 4-5 (2008): 453-87, at 469 .

${ }^{56}$ Burnett, Vincent, and Mayall, The Autobiography of the Working Class, 1:278.

57 * Sam Shaw, Guttersnipe (London, 1946), 28-29.

${ }^{58}$ Bennett, "In the Workhouse"; * Edward Balne, "Autobiography of an Ex Workhouse and Poor Law School Boy," 1-3, Burnett Archive, Brunel University Library, London, https://bura.brunel.ac.uk/handle/ $2438 / 9415$. 
Edward Tufnell to write it. Ross went from a "little heathen" destined for prison to becoming a workhouse schoolmaster in later life. ${ }^{59}$ John Castle's autobiography described a childhood and adolescence of increasing poverty and marginalization with his departure from the workhouse marking the lowest point, followed by an adulthood of agency and productivity. ${ }^{60}$ Castle was seventeen when he was admitted to the house of the Leighton Buzzard Union in 1837, along with his older brother and sister-in-law. Leighton Buzzard workhouse was an early, mid-sized institution built in 1836 to accommodate 350 people. ${ }^{61}$ Castle was resident for only a short time before a minor misdemeanor roused the attention and anger of the chairman of the Guardians. He was told he would be sent out of the house, despite (and therefore in contravention of the provisions of the law) Leighton Buzzard being his place of legal settlement and his having no other means of support. On 1 April 1837, he was escorted to the gate, given four shillings, and told to "go for a soldier." Distantly aware that this was not legitimate, Castle retorted that after he had spent the money, he would be brought back, to which the relieving officer said, "We won't have you." Castle left and "wept bitterly. . . till . . . my eyes seemed swollen in my head."62

Castle's misery was twofold in that he was forced to separate from his brother and was being removed from an institution of last resort. Yet his fortunes improved dramatically after he found work in London, and eighteen months later he reappeared at the Leighton Buzzard workhouse door "in a different character from the one I was expelled with." He went back for a social visit: "I pulled the bell out came poor old Culverhouse, the Porter, bowing at me, thinking I suppose, I might be some Inspector, I smiled at him and said 'Don't you know me Culverhouse?'. . . he shook hands and said 'Come in, Mr Bromley will be glad to see you', and so he was . . . the Master took me into the men's ward there I saw several faces I knew. . . I made myself known to them, gave them a few pence and bade them farewell."63 Reports in the nineteenth-century press sometimes suggested that paupers returned to workhouses after their discharge, perhaps to partake in Christmas dinner, providing workhouse philanthropists with an opportunity for display. ${ }^{64}$ Castle returned for his own purposes. He was clearly proud of himself, a young man transformed, now bestowing beneficence rather than a supplicant having relief withheld.

Other memoirists chose the model of a highly positive construction of self within institutional walls. Joseph Bell offers one of the two most sustained portraits of life in a workhouse, since half of his surviving two-hundred-page typescript is devoted to his memories of the Bedford Union workhouse school. His account ends at the point of his apprenticeship at thirteen, so his later career as a master bootmaker in St. Albans is entirely omitted, and he sidesteps the opportunity to showcase his occupational achievements. Instead, he recounts his personal and educational successes

\footnotetext{
${ }^{59}$ Ross, in Tufnell, "Education of Pauper Children," 255. Tufnell included Ross's narrative in his reports to Parliament.

60 * "The Diary of John Castle" [written 1871], Burnett Archive, Brunel University Library, http://bura. brunel.ac.uk/handle/2438/9430.

61 "Leighton, Buzzard, Bedfordshire," in The Workhouse: The Story of an Institution . . (website), comp. Peter Higginbotham, accessed 1 July 2019, http://www.workhouses.org.uk/LeightonBuzzard/.

62 "Diary of John Castle," 8.

63 "Diary of John Castle," 12.

${ }^{64}$ Laura Foster, "Christmas in the Workhouse: Staging Philanthropy in the Nineteenth-Century Periodical," Journal of Victorian Culture 22, no. 4 (2017): 553-78.
} 
while still at school, alongside an indicative commentary on his feelings. Born in 1846, Bell had three older sisters when he was orphaned in 1858. At the workhouse school in Bedford, he quickly made friends among the boys and became acquainted with the wider cohort of workhouse inmates. In direct contrast to Charles Shaw's dread of bedtime and bigger boys terrorizing the dormitory, Bell relished the prospect of telling bedtime stories to his peers. An early schoolyard fight apparently established him as "a great favourite," and he repeatedly describes himself at this time as "quite happy" or "very happy." boy." 66 Bell credits himself with becoming something of a leader, well regarded by staff, inmates, and pupils alike, capable of extensive agency. In illustration of the latter, he claims to have instituted the practice of children managing patches of the workhouse garden and to have run illicit errands for adult inmates when he undertook official commissions in the town of Bedford.

He became thoroughly disenchanted by school life when after a residence of about six months he was subjected to fierce corporal punishment, but even this event demonstrated an exercise of choice. He was beaten for refusing to reveal the authorship of an inflammatory letter, and although he had composed the letter (in defense of the head girls), others physically wrote it. He withheld the names of his collaborators and felt very harshly treated with the punishment of bread and water and twelve strokes of the birch. He took solace in his determination to be punished alone, however, and was given retrospective approval by a teacher for his loyalty to his friends, thus construing this miserable episode as an example of his assertion of autonomy. He left school for an apprenticeship at the earliest opportunity in defiance of advice from his teacher.

In these ways, working-class authors give a variety of accounts featuring Poor Law residence as a child, which could be said to cover an emotional range from child as dispossessed victim (Charles Shaw) to child agency triumphant (Bell). They tacitly illustrate the difficulty for authors forced to accommodate such memories following admission in adulthood, because there is only one core narrative dealing with the "in and out" experience of adult inmates in workhouses proper (as opposed to its vagrancy wards) that is a recognized feature in workhouse historiography, and it is too problematic to use here. ${ }^{67}$ Collectively, though, the accounts discussed here push the range of stories about Poor Law institutions beyond easy assumptions about a Dickensian model and problematize our understanding of the workhouse and associated residences in paupers' emotional lives and life courses. Closer attention to two of these narratives, from autobiographers who offer drastically divergent accounts of time spent in a London workhouse district school, further exposes the tensions and evasions inherent in life writing that juxtaposes institutional guardianship with familial alternatives.

${ }^{65}$ Bell, "Chapters from the Autobiography of a Village Lad," 125, 131.

${ }^{66}$ Bell, 116, 190.

${ }^{67}$ Crowther, Workhouse System, chap. 9, especially 227, 232-33. This narrative was a sardonic exposé by an adult inmate of the Poplar Union workhouse, * [J. Rutherford], Indoor Paupers by "One of Them": Life Inside a London Workhouse (n.p., 2013). It is inappropriate for consideration alongside the other core narratives, as it contains no context to the author's life at all, and even the authorship was long in doubt. 


\section{MEMORIES OF DISTRICT SCHOOLS}

District schools were first advocated in the 1830s as a way to provide a combination of education and industrial training to pauper children who would then enjoy a life of independence without need for welfare. The schools were designed to accommodate children from a number of Poor Law unions while spreading the cost, but despite both the fond hopes of influential promoters like Edward Tufnell and the enabling District School Act of 1848, only ten were opened before 1880.68 Those that were established followed a conventional academic curriculum but tended to enjoy very good facilities for selected non-academic pursuits such as sport and music. Boys and girls still in the schools when they reached fourteen entered military or domestic service respectively. ${ }^{69}$

The schools were supposed to remove children from the contaminating atmosphere of adult workhouse pauperism, so while workhouses have been seen as embedded within communities, district schools were decisively isolated from them. ${ }^{70}$ Schools catered for more than one workhouse and intentionally pulled children even further from their families, logistically and geographically, which could inhibit parents' visits to children. Schools eventually became part of a Poor Law policy trend to ameliorate children's exposure to the workhouse proper; the smaller-scale cottage homes for children instituted in selected locations from the 1870s were another reflection of this trend. ${ }^{71} \mathrm{With}$ hindsight, though, institutional separation from workhouses was unlikely to be effective on its own in attenuating the pauper "taint." Children remained under the authority of the Poor Law Board or its successors, and both schools and cottage homes were subject to the same concerns about financial stringency as other institutions. The district schools also drew on Poor Law precedents for diet, staffing, and organization (both within buildings and by apportioning hours in the day) including Poor Law directives about corporal punishment. Autobiographies have previously been deployed to argue that district schooling was primarily characterized by physical discipline and a stultifying curriculum that proved every bit as punitive as the predecessor workhouse regime. ${ }^{72}$

It was beyond the remit or capacity of schools to monitor children's subsequent independence from welfare. Conversely, it was in Edward Tufnell's interest to demonstrate the schools' effectiveness, and he was one of the few to attempt mapping children's subsequent careers by soliciting correspondence from former pupils; his personal investment in the district-school project inevitably renders his anecdotal positivity suspect. ${ }^{73}$ Fortunately, protracted autobiographical accounts of school life by former pupils can be scrutinized in two contrasting ways to reveal more about the place of the institution in an individual's life course. First, the tenor and content of the text can be positioned in relation to the character of other available

\footnotetext{
${ }^{68}$ Janet Elizabeth Livingstone, "Pauper Education in Victorian England: Organisation and Administration within the New Poor Law, 1834-1880" (PhD diss., London Guildhall University, 1993), 55.

${ }^{69}$ Susan Stewart, "The Children," in The Central London District Schools 1856-1933: A Short History (London, n.d.), n.p.

${ }^{70}$ Murdoch, Imagined Orphans, 97.

${ }^{71}$ Fowler, Workhouse, 139.

${ }^{72}$ Livingston, "Pauper Education," 71-76.

73 Tufnell, "Education of Pauper Children," 245-47. Ross's memoir, favoring the district school over the workhouse, was generated solely at Tufnell's request.
} 
narratives to find what the authors are willing to reveal about the material and emotional impact of their residential experience, marrying discursive formulation with practical activity. ${ }^{74}$ Second, the texts can be compared with the broader historical record to find coalescences and divergences between the autobiographical story and the relatively neutral entries in parish registers, censuses, institutional admissions and discharge records, and mundane Poor Law-related correspondence (so not merely those documents associated with a particular scandal or inquiry). This comparison is not used as an exercise in catching out authors whose memories were faulty as to specific dates or events but instead provides an opportunity to evaluate individual writers' own estimation of their lives against that of an array of alternative witnesses to their lives, families, and careers-witnesses who, however self-interested, were not hailing from the same perspective or with the same agenda as the autobiographer. ${ }^{75}$ This work demonstrates that the narratives broadly aligned with either Oliver Twist or self-improvement cannot contain institutional memories without extensive adaptation. Those models prove insufficient in ways that are both positive and negative for district schools' reputations and for the family as a preferable antithesis to intervention via the New Poor Law.

One of the longest and most accessible accounts of district school life makes a clear statement about the lasting harm that institutional living inflicted on the author, arising from abuse that went far beyond simple nutritional or emotional deprivation. It is written in the Oliver Twist vein by a man who admired Dickens above all other writers but who-in contrast to Oliver, who is presumed to have put his childhood sufferings behind him by the novel's end-suffered drastic trauma and no significant emotional recovery from childhood oppression. Frank Stone was born in 1860 and died in 1939. His autobiography, Ditcher's Row, which appeared under the pseudonym Frank Steel, runs to nearly three hundred pages, with his account of life in a workhouse district school occupying more than a third of the narrative. ${ }^{76}$ The author's introduction makes this emphasis the justification for his writing, on the grounds that to his knowledge no other published account dealt with these schools. Yet, like other autobiographies, it begins with his parents and his earliest memories. These reminiscences can now be augmented with genealogical research into specifics.

Stone's father, Edwin, married the much younger Emma Purkin in Camberwell in 1856 , and the couple quickly had three sons, whose places of birth give testimony to the household's frequent removals across Middlesex and Hertfordshire. ${ }^{77}$ Edwin was described in various documents as a draper's assistant, then publican, engineer, sawmill proprietor, and later timber merchant (glossed by Frank Stone as a traveling salesman of the laths for venetian blinds). The family's poverty by the time of Frank's

${ }^{74}$ This amalgamation is borrowed from Roper, "Slipping out of View," 63.

75 Carolyn Steedman, Past Tenses: Essays on Writing, Autobiography and History (London, 1992), chap. 7.

76 Steel, Ditcher's Row, 101, 199. Steel's legal identity as Frank Stone is confirmed by his correspondence with his publishers: see MS Sidgwick and Jackson 82, letter book 1938-9, fols. 842-43; MS Sidgwick and Jackson 83, letter book 1939, fols. 133, 477, 915, 947; MS Sidgwick and Jackson 84, letter book 193940, fols. 139, 372, 610, 700, 748, Bodleian Library, Oxford.

${ }^{77}$ Edwin Stone and Emma Purkin, marriage certificate, 6 April 1856, Camberwell District, General Register Office ref. vol. 1d, p. 614, copy in possession of author; The National Archives (hereafter TNA), RG 11, General Register Office: 1881 Census Returns for 129 Goswell Road, Clerkenwell, Middlesex. 
early childhood was palpable. He recalls an incident of a dropped half sovereign, and the despair on his mother's face when it had to be given up as lost. Her anguish is unsurprising given that Edwin had already spent time in the Whitecross Street debtor's prison and suffered subsequent bankruptcy. ${ }^{78}$

Stone's autobiography clearly argues that his parents were not to blame for their financial misfortunes. He is quick to exonerate his father and implicate instead "a hard, mean, ill-regulated world that, instead of affording recognition and a place for every kind of merit, reserves its favors for the 'strength' of selfishness and cunning." ${ }^{\prime 79}$ If his father had any fault, it was that "he lacked acquisitiveness and 'shove," being too gentlemanly for business. Similarly, Emma Stone was credited as "the embodiment of the genius of motherhood," maintaining the idea of home even when circumstances deprived the family of the material means. ${ }^{80}$ That said, the nonjudgmental reasoning Frank gives for the family's poverty does rest on Edwin, whose periodic indolence, diffidence about his financial state, and generosity to others did not tend toward solvency. Stone recalls Emma saying that, given her time over, she "would never again sit back worshipping masculine wisdom and holding my peace till the mischief was done." 81 This parental portrait underscores "a model of unemployed fathering not as failure but, rather, as fragility." 82

Frank Stone was admitted to the workhouse in Hackney in the summer of 1868 and swiftly transferred to the Forest Gate District School, along with his brother Henry (identified as "Reggie" in the narrative), one year his senior. ${ }^{83}$ The brothers remained at Forest Gate until April 1872, when their nuclear family regrouped. ${ }^{84}$ The school in East London had only been open for a matter of months when Stone was admitted, although the buildings had previously formed the premises of an industrial school for the Whitechapel Union, and Forest Gate inherited a number of its staff. It was a fairly large establishment, catering for seven hundred to nine hundred children, with predictable divisions between boys and girls, younger and older children. ${ }^{85}$

Stone's account spans the launch and development of a social movement against outdoor relief and the alleged philosophical shifts it caused to the Poor Law per se. In 1869, a pamphlet known as the "Goschen Minute" appeared, recommending a return to the principles enshrined in the Poor Law as enacted in 1834 and a crackdown on any money or welfare being issued to the poor outside of workhouses. The call to action inspired the movement known as the "crusade against outdoor relief." 86 Nonetheless, Stone makes no explicit mention of the crusade, and his experiences

\footnotetext{
78 "The Bankruptcy Act, 1861. Notice of Adjudications and First Meeting of Creditors," London Gazette, 29 September 1863, 4719-25, at 4720.

79 Steel, Ditcher's Row, 11.

80 Steel, 26.

81 Steel, 29.

82 Strange, Fatherhood, 19, and chap. 2.

${ }^{83}$ Frank and Henry Stone were admitted to the Forest Gate School soon after its opening; Livingstone, "Pauper Education," 320.

${ }^{84}$ Forest Gate District School 24, creed register 1861-1871, 208, London Metropolitan Archives; Forest Gate District School 25, creed register 1861-1881, 151, London Metropolitan Archives.

85 TNA, MH 27/101.

${ }^{86}$ G. J. Goschen, Letter of the Rt. Hon. G. J. Goschen, President of the Poor Law Board: On the Relief to the Poor in the Metropolis (London, 1869).
} 
were entirely disconnected from it, since his time as a pupil was tortuous from 1868 to 1870 and improved thereafter. Stone's is undoubtedly a trauma narrative, quite possibly written in an attempt at self-analysis, to achieve a form of therapy and relieve pain. ${ }^{87} \mathrm{He}$ felt a lifelong sense of emotional disablement deriving from his sufferings in youth, and specifically from his time at residential school. He concludes his memoir with a deeply depressed summation: "As I look back over my life, what do I see down all the vista of years but long drab stretches of discouragement and disappointment; of hopeless, or but half-hopeful because always cramped and hindered, endeavour; of heart-breaking hope-deferred; Just as one was thinking: 'Here comes the sun at last!'- the cheering rift closed in and all was overcast again." 88 Stone viewed the place of the school in his life course as wholly negative; it did not insure him against poverty in adulthood and seemingly guaranteed a lifetime of disappointment and shame.

His account of school life comprises authentic and disturbing evidence of physical and psychological abuse by a single member of staff, which in hindsight coheres convincingly with the effects he describes. Separated from his brother by the internal management of the school, Stone was allocated to the care of a boys' nurse whom he called "Kate." This was Catherine KcKennon, age twenty-two in 1868, who had domestic charge of all of the younger boys at Forest Gate while they were not being taught. ${ }^{89}$ According to Stone, she was a violent custodian of pauper children, repeatedly and daily smacking the boys in her care with her hands or a wooden battledore, on the face, limbs, and elsewhere on their bodies. He recalled that her brutality was expressed most intensely in relation to illness among the children; chilblains or ophthalmia (severe conjunctivitis) were guaranteed to result in a beating. According to Kate's philosophy, illnesses were amenable to punishment because she believed that the children induced them willfully by, for example, rubbing their eyes, in order the secure admission to the school's infirmary. She applied her own version of "treatment," which in the case of chilblains involved holding hands or feet in the fire until they were burned. Stone records the sense that she relished the power of chastisement, noticing her "smirk of malicious enjoyment" at the children's evident fear. In addition to suffering physical violence bordering on torture, the boys were abused verbally; in piercing, scornful tones" and a "spiteful taunting drawl," Kate would castigate them as "varmins" or, more sinisterly, as "my beauty." 90

This sort of egregious punishment was not endorsed by the Poor Law Board, and by implication it was forbidden, so if Stone was recalling Kate's chastisements accurately, she was drastically exceeding her remit. Children in district schools were subject to the same rules of punishment as their counterparts in internal workhouse schools, where regulations on punishment were set by the Poor Law Commissioners' report of 1841 and made part of a General Order of 24 July 1847. The regulations forbade any corporal punishment of female children and technically restricted the delivery of physical punishments to male children under fifteen by the workhouse master or schoolmaster. Punishment of male children was to be inflicted only with

${ }^{87}$ Gagnier, Subjectivities, 45.

${ }^{88}$ Steel, Ditcher's Row, 297-98.

${ }^{89}$ Forest Gate District School 40, List of Officers 1868-87, London Metropolitan Archives; TNA, RG

11, General Register Office: 1881 Census Returns.

${ }^{90}$ Steel, Ditcher's Row. 
an approved form of rod, and only then after six hours had elapsed after the detection of the offence. Female nurses were not included as potential sources of chastisement. ${ }^{91}$ Unequivocal prohibition of physical punishment by female attendants was presumably thought to be unnecessary, or the requirement for such prohibition simply did not occur to the board. The specific rules governing Forest Gate were an adaptation of these earlier statutes, and while the lapse of time between misdemeanor and punishment was reduced to two hours, the other provisions remained. ${ }^{92}$ Therefore, while Stone could attribute Kate's occasional referrals of boys to the headmaster for punishment only to "a spice of deep-laid diplomacy," we can appreciate that strappings by the schoolmaster were the only legitimate punishments applied. ${ }^{93}$

Kate was one employee among many at Forest Gate, and Stone acknowledged that other nurses, teachers, and officers at the school were not guilty of such grotesque behavior. When he was promoted to join the older boys, his life changed dramatically; "Starved and stunted might be (and were) our lives; and we had our troubles in class and among our fellows, of course, as all schoolboys have; but the 'reign of terror' was over for me." ${ }^{4}$ Unusually, he speculated on the forces that drove "Kate" to behave in such a way and concluded that there was no systematic policy or requirement to terrorize the children but that she affected these methods out of personal vanity and to secure advancement. ${ }^{95}$ Her career within the school suggests he may have been partly right, inasmuch as her transfer to the girls' infirmary in 1871 resulted in an increase in her pay from $£ 14$ to $£ 18$ per annum. ${ }^{96}$ Stone construed her painful treatments for minor ailments as an attempt to keep the children in her charge off the school's infirmary register. What he could not have known at the time, and may not have appreciated in retrospect, was that the general health of children in London's district schools had become a matter of parliamentary scrutiny, and that rates of ophthalmia in the schools and the consequential risk of children losing their eyesight was a burgeoning national scandal. ${ }^{97}$ It was also the case that the school's medical officer, Thomas Vallance, endorsed Kate's view that the children invited eye infections, telling the Poor Law Board that "the evil is the recurrence of attacks in the same child, very frequently however produced by themselves for the purposes of getting to the infirmary." 98 Stone would hardly have understood these factors as mitigation for Kate's alleged behavior, but it does suggest a context of general institutional pressure and a specific desire to drive down the spread of eye infections that was felt by the children's nurses.

In this way, Stone's interpretation of his residence in the district school places heavy emphasis on the contingency of staff characteristics, which were in themselves

${ }^{91}$ Great Britain Poor Law Commissioners, Seventh Annual Report of the Poor Law Commissioners, with Appendices (London, 1841), 72, 75.

92 TNA, MH 27/101, Lunatic Asylums, Psychiatric Hospitals and Mental Health.

${ }^{93}$ Steel, Ditcher's Row, 128

94 Steel, 196.

95 Steel, 118-19.

${ }^{96}$ Forest Gate District School 40, list of officers, 1868-87, London Metropolitan Archives; TNA, MH 27/102, Lunatic Asylums, Psychiatric Hospitals and Mental Health.

97 Times (London), 27 November 1873; Fourth Annual Report of the Local Government Board, 1874 75, 1875, C-1328, at 55-131.

98 TNA, MH 27/101, Lunatic Asylums, Psychiatric Hospitals and Mental Health, letter of 17 October 1868. 
shaped by structural forces as well as personality. The institution does not escape without inherent blame, as "the system's machinery of humbug" provided a facsimile of care rather than its reality. But it was Kate's unfettered physical authority that made Stone's life hellish. The punitive years of life in the district school were also given definition by the staff who did not conform to Kate's model of cruelty. The receiving wards (opened to provide a barrier to whole-school infection by new admissions) were administered by "angels of loving kindness as compared with that fury Kate," Stone wrote, and an intervention by a young male teacher resulted in "the most truly wonderful moment of my life" (namely, his discovery of a fine singing voice). ${ }^{99}$

Stone's account also demonstrates, in a more muted way, the role of family dynamics in framing the place of the workhouse and school in his memory. Stone recalls his father's admission to the workhouse with as much horror as his own, induced by seeing Edwin in the institution's shameful corduroy attire. Stone took up some of the emotional burden of his father's admission without apparently being able to share his own feelings with other family members. When the boys were transferred to the school, his older brother Henry lay out of Kate's jurisdiction from the start and instead fell under the care of a male supervisor, "easy-going Old Jerry." The brothers had very different exposure to the school's staff, and, like many victims of abuse, Frank felt he could not tell Henry the full range of his sufferings. ${ }^{100}$

The autobiography also raises questions around the termination of Stone's school experiences, which points to family choices exacerbating the institutional experience. Frank and Henry were given no intimation that their stay at Forest Gate was coming to an end. One day they were summarily transferred back to the Hackney workhouse, where they met their father and walked away to resume their home life. Thereafter their mother referred to her time in the workhouse "seldom" and their father "never." 101 What informed the decision to regroup, and the timing of the boys" leaving school?

Emma Stone sought her release from the workhouse relatively early to set up a cook shop in Shoreditch and was not joined by her husband and children for an unspecified amount of time. When Frank and Henry were discharged from school, it was to an immediate transfer to working life. Did their mother permit them to remain in Forest Gate for longer than might have been the case, perhaps to extend their education and prevent their having to go out to work at an even earlier age? Other parents of children in Forest Gate took quite a different line in their deployment of resources provided through the Poor Law; in the two decades after Stone's admission, Sarah Harrison's daughters were admitted and discharged from the school up to fifteen times after stays of months or mere days. ${ }^{102}$ The shortterm stay was much more characteristic of children's institutional life than the exposure for years at a time, and parents manipulated children's discharge dates to avoid their being sent from workhouses to district schools. ${ }^{103}$ Therefore, the duration of the Stone brothers' school residence, and the very occasional character of their

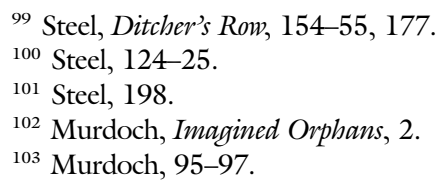


contact with parents, was probably as much a matter of parental choice as compulsion.

Stone did not question the terms of his leaving school, at least not within the scope of his autobiography, despite the dispiriting period that followed. He worked long hours for low wages and plowed all of his earnings into the maintenance of his parents and their repeatedly failing schemes for income. He took a sort of universal discouragement from these experiences, summed up as "Don't attempt anything! The cards of the system are stacked against you, and you are bound to lose!"104 Superficially, this makes him look something like the passive victim of economic determinism, a type familiar in other non-Poor Law narratives. ${ }^{105}$ But in Stone's estimation, his family was uniquely victimized, not as part of a group, because others appeared to succeed where they failed. Yet while his parents are never identified unequivocally as at fault in his memoir, they were clearly contributors to the length of his stay at school, his need for employment no matter the terms, and his crushing sense of inevitable failure.

Similarly, Stone's claim for an unalleviated, depressive emotional legacy arising out of institutional residence is out of alignment with the observable historical record and with Stone's material fortunes in the second half of his life course. Success came to him in his thirties, significantly a period not much covered by his autobiography. He moved first to Canada and then to California, at least in part because of his wife's health. The couple had two children, and Stone became an artist in medallion portraits and sculpture. He worked within the state but exhibited nationally, winning a gold medal at the Alaska-Yukon expo held in Seattle in 1909. ${ }^{106}$ This startling postemigration résumé is indicated only faintly in the book by very scattered reference to his later artistic career. ${ }^{107}$ Furthermore, he was ambivalent about broadcasting his account at all: correspondence with the publishers Sidgwick and Jackson proves that he had a draft available by 1919, resubmitted it in 1926, and only finally released the third attempt in 1939.108 Yet even as he makes a convincing case for his life having been scarred by failure, he became to outward appearance a commercial success.

Stone's autobiography has been used in passing by several historians to illustrate the long-term stigmatizing effects of institutional life under the New Poor Law, without the realization that he wrote pseudonymously. ${ }^{109}$ But Stone's is not the only account of district-school life, and it is not as unequivocal in its implications as might first appear. To read this memoir as the only possible account of the schools risks "mistaking the exceptionally brutal for the average." 110 Just as the character or behavior of institutional employees, and harsh family choices, could have a negative impact on children, the reverse could also hold true. ${ }^{111}$ Discretionary action

\footnotetext{
104 Steel, Ditcher's Row, 247 (emphasis Steel's).

105 Gagnier, Subjectivities, 43.

106 "Frank Frederick Stone (1860-1939)," askArt, accessed 1 July 2019, http://www.askart.com/artist/ Frank\%20Frederick\%20Stone/10052120/Frank\%20Frederick\%20Stone.aspx.

107 Steel, Ditcher's Row, 215, 239-42, 271-72, 278.

${ }^{108}$ Bodleian Library MS Sidgwick and Jackson 82, letter book 1938-9, fol. 842.

109 Walker, "Accounting, Paper Shadows" 469; Doolittle, "Fatherhood and Family Shame," 97-98.

110 Adams, "Last Years of the Workhouse," 113.

111 Adams, 115.
} 
by employees might conceivably work in paupers' favor where individuals were kindly disposed, and dysfunctional families might put the district school into an entirely different light in other life narratives. Stone's own acknowledgment of debts to staff other than Kate, and his review of his family finances, both begin to point in this direction.

The Central London District School at Hanwell was an early foundation in the district school movement, since it was built from 1856 onward and was predicated on an earlier school at Norwood. It was a large institution, catering for around twelve hundred children. ${ }^{112} \mathrm{~A}$ small run of former pupils described their experiences at the school in later life; the most famous of these was Charlie Chaplin, whose account spans the child-victim/self-improvement models. ${ }^{113}$

Two further narratives stretch the depiction of district schools much further, by demonstrating active enjoyment of institutional living at Hanwell and either a wariness or tacit rejection of family life, at least during childhood. Ada Bennett (b. 1901, cited in the introduction) and Edward Balne (1894-1983) were both residents of the Central London District School at Hanwell in Middlesex between 1903 and 1913. ${ }^{114}$ The time-lapse between Stone's discharge from Forest Gate and the arrival of these two children in Hanwell potentially allowed for improvement in school conditions between the 1870s and the 1910s. There was the scope for "real" change, effected by the introduction of female and working-class Poor Law Guardians from 1875 and 1892 respectively. Bennett's receipt of sixpence at New Year seems to speak to this sort of progress. Nonetheless, two additional points are indicative. First, observers and managers of district schools remained concerned about many of the same issues that had exercised their predecessors and became more attentive to the ways that large district schools might not be well suited to child welfare, yet schools remained open into the mid-twentieth century. ${ }^{115}$ Second, both Stone and Balne clearly ascribe the extremities of their experience to individual abusive personalities, inside or outside schools.

Edward Balne's time at Hanwell is described in emphatically nostalgic terms. Born in 1894, he may never have lived with his parents; he mentioned that he did not remember ever having met them. ${ }^{116}$ His earliest memories were of the Southwark workhouse, where he was apparently treated with kindness; later he was sent to Hanwell and remained there until 1909. Balne and his fellow schoolchildren identified parent substitutes among the teaching staff, most notably in "Daddy" Wadsworth. ${ }^{117}$ Balne recalled with pleasure his own prowess at cricket and his

112 "Central London School District," in Higginbotham, comp., The Workhouse, accessed 5 July 2013, http://www.workhouses.org.uk/CentralLondonSD/.

${ }_{113}$ Chaplin, My Autobiography, 22-26.

114 Stewart, Central London District Schools.

115 Poor Laws School Committee, Report of the Departmental Committee Appointed by the Local Government Board to Inquire into the Existing Systems for the Maintenance and Education of Children under the Charge of Managers of District Schools and Boards of Guardians in the Metropolis and to Advise as to Any Changes That May Be Desirable, 1896, C-8027. On the schools' existence well into the twentieth century, see Stewart, "Afterwards," in Central London District Schools.

116 Sandford Row School Admission and Discharge Register for Boys, 1889-1903, LCC/EO/DIV08/ SAN/AD/001, London Metropolitan Archives, giving birth date of 17 November 1894; Balne, "Autobiography," $1-3$, giving parentage.

117 Balne, "Autobiography," 6. 
enjoyment of his musical education (he became a trumpeter). He characterized the school as having been his home for twelve and a half years of his life and felt it "a great wrench" to leave to enter the army as a bandsman at age fourteen. ${ }^{118} \mathrm{His}$ subsequent career in military service included severe injury at Gallipoli. Balne's comparative physical enjoyment of youth at Hanwell is therefore tacitly contrasted with disablement in adult life and considerable pain conferred by a lengthy experience of kidney disease.

In composing this history, Balne was consciously or unconsciously editing his wider birth family out of his childhood memories. Close attention to the admission and discharge records of Hanwell reveal that he was not admitted until age eight, and this later admission is confirmed by the 1901 census, which clearly identifies him, as age six, living in Newington as the adopted son of Charles Balne (a paternal uncle), Charles's wife, Margaret Balne, formerly Ashworth, and the couple's three natural children. ${ }^{119}$ The household probably broke up in the wake of Margaret's death in 1903, when the couple's youngest natural child was already thirteen but Balne was only eight. He was admitted first to Newington workhouse, then Hanwell District School, just a few months after Margaret died. ${ }^{120}$ Thus he had clear experience of domestic life at an age when he should have remembered it, but he writes this period entirely out of his memoir to concentrate on Hanwell instead. The school was certainly aware of his adopted family, because it listed his nearest known relation as "Mrs Ashworth" (possibly the wife of one of Margaret Balne's sons by her first marriage). ${ }^{121}$

Yet at the outset of Balne's account, he writes, "I have never known a single personal relative" excepting only those by marriage. ${ }^{22} \mathrm{He}$ does not mention the wider Balne family subsequently in his written recollections, and he even presses home this point when he recounts being invalided out of the army: on release from hospital in 1916, he lodged with the parents of a fellow army bandsman, "having no home of any sort or relatives." 23 This rejection of family fits with a different narrative tradition, but not one found very readily among working-class autobiographies. Instead, it speaks to the refrains of philanthropic reformers throughout the Victorian and Edwardian periods who stereotyped children as orphans or deserted by parents. Lydia Murdoch has charted the fracture lines between these stock representations of poor children by middle-class commentators and the everyday usage of charitable and Poor Law services by poor families, with particular attention to the increasing vilification of parents from the 1870s. ${ }^{124}$ Balne's memoir

118 Balne, 23-27, 37.

119 Central London District School 229, creed register 1908-1912, London Metropolitan Archives; TNA, RG 13, General Register Office, 1901 Census Returns.

${ }^{120}$ Margaret Balne, death certificate, 3 May 1903, Camberwell District, General Record Office, ref. vol. ld, p. 411, copy in possession of the author.

${ }^{121}$ For another autobiography at odds with the census record, see Copeman, Reason in Revolt, where the author describes being transferred from the Wangford Union workhouse to the Beccles children's cottage home at age nine or ten, when the 1911 census puts him in the cottage home at age four.

122 Balne, "Autobiography," 3; Edward Balne and Jessie Hill, marriage certificate, 15 October 1928, Islington District, General Record Office ref. vol. 1b, p. 634, copy in possession of the author.

123 Balne, "Autobiography," 97.

${ }^{124}$ Murdoch, Imagined Orphans, 2-6. 
avoids the reformers' trope of parental abuse and exploitation of children but aligns decisively with their invested optimism in institutional provision.

Even if Balne did not remember his biological family, someone among their number would have remembered him. At the time of his admission to school, both of his parents and at least two siblings were alive. Edward Thomas Balne and Caroline Dinah Balne, née Reeves, had married in 1885 and had at least five children born alive: Violet, Thomas, Edward, Albert, and Reginald. ${ }^{125}$ Violet and Reginald died in infancy, but the family household in 1901 comprised both parents and their sons Thomas and Albert. ${ }^{126}$ Caroline died in 1908 and Edward senior in 1915, while Edward's two older brothers grew up from at least 1911 with the Reeves family. ${ }^{127}$ Only Edward was cut adrift from his parents' relations. He may have been entirely unaware of the fact, so nothing firm can be drawn from their omission in his autobiography, but his upbeat investment in Hanwell District School is rendered more notable. The elision of the entirety of Balne's early life with his school days, and his adherence to the line that he had no effectual relationship with members of his birth family, means that the school and army peers acted as his surrogate family in a way that he firmly embraced.

Balne's apparent neglect by his parental families does invite consideration of the multiple ways that families could fail, short of parental death. Caroline Balne died of phthisis in 1908 while living with her brother. ${ }^{128}$ This eventual diagnosis, plus the distribution of the couple's children among aunts and uncles, gives rise to a number of possibilities for the life choices of Edward and Caroline Balne in the period between the memoirist's birth in 1895 and his mother's death in 1908. Did the parental couple choose to give up their middle child, or was their hand forced or encouraged by other factors such as Caroline's developing illness, which eventually killed her? Did they suffer a breakdown in their marriage, prompting Caroline's retreat to a sibling's household? None of these options would have been unremarkable in themselves, but the resulting events did leave Edward Balne Jr. isolated and institutionalized when his brothers were not, and the story opens up the possibility of other failings by parents that were less coincidental or blameless. Parents could treat children differently or neglectfully if there was some question over their legitimacy, for example - could Caroline have had an extramarital liaison that resulted in Edward Jr.'s birth?

\footnotetext{
${ }^{125}$ Violet Balne, baptism, 26 July 1890, St. Olave, Bermondsey, London Metropolitan Archives, ref. no. p71/pau/006; Violet Caroline Elizabeth Balne, burial, 31 July 1890, Newham, Deceased Online, https:// www.deceasedonline.com; Thomas Balne, birth certificate, 29 January 1892, St. Saviour, Southwark District, General Register Office ref. vol. 1d, p. 21; Albert Balne, birth certificate, 27 March 1896, St. Saviour, Southwark District, General Register Office ref. vol. 1d, p. 14; Reginald Balne, birth certificate, 31 August 1899, St. Saviour, Southwark District, General Register Office ref. vol. 1d, p. 14; Reginald Balne, burial, 31 July 1900, Newham, Deceased Online, https://www.deceasedonline.com. All baptism or birth records for Violet, Thomas, Albert, and Reginald Balne confirm that their father was Edward (that they and the autobiographer had the same father).

126 TNA, RG 13, General Register Office, 1901 Census Returns.

${ }_{127}$ Caroline Balne, death certificate, 1 September 1908, Southwark District, General Register Office ref. vol. 1d, p. 16, copy in possession of the author; Edward Balne, death certificate, 21 August 1915, Camberwell District, General Register Office ref. vol. 1d, p. 738, copy in possession of the author; TNA, RG 14, General Register Office, 1911 Census Returns.

${ }^{128}$ Caroline Balne, death certificate, 1 September 1908, Southwark District, General Register Office ref. vol. 1d, p. 16, copy in possession of the author.
} 
In addition to the marked absence of family, there is a second and unique feature to Balne's account. He describes the moment when he says he was made to realize his marginal life status. This took place not in school but in the community. Balne was routinely chosen to score for the local adult's cricket team, and one Saturday, he writes,

I first became conscious of my lowly status in society. And being a highly sensitive lad, I was never to forget the incident (which I will not describe here) which occurred that afternoon. The shock of the realisation that I was considered to be a member of the lowest form of human creation was an experience from which I have never fully recovered. It affected my nerves and my whole outlook upon life. It affected my confidence and personality and it left a feeling of a deep and profound inferiority complex which generally has overshadowed everything I have tried to accomplish over the years. ${ }^{129}$

Like Frank Stone, treatment in childhood delivered by a single person blighted Edward Balne's emotional life, but unlike in Stone's case, these feelings were not instilled exclusively by an institution or by an adult employee. Rather, he was given some sudden, cruel (and, given his reticence, possibly sexually abusive) induction into the stigmatizing effects of the Poor Law by someone, presumably an adult man, outside of the relief system. For Balne, the Hanwell District School had in effect operated like a protective family shielding a low-status member from stigma. ${ }^{130}$ The realities of life beyond or after district school were perhaps part and parcel of having been a pauper child, but the school itself could be construed with hindsight to mitigate the classification of pauperism and be viewed as a site of contentment and quasifamilial significance before the trials of adulthood.

\section{CONCLUSION}

Historians of the emotions have considered the scope for sweeping change in the bodily experience and expressive diction of feeling. They have generally pointed to the greater assertion of emotional control over time, combined with oscillating localized trends. This study has taken a much narrower focus: the emotional communities among former inmates of Poor Law institutions, where the sentiments of recollection were not explicitly driven by central policy change but by a combination of personalities, family context, later experience, and preexisting narrative models available for co-option.

The Oliver Twist narrative offered one model for this emotional community of those affected by the Poor Law, but the diversity of narratives beyond the Dickensian option make two things plain: first, the scope for institutional abuse and de facto psychological scarring have been underestimated in even the most drastic popular stories, which have dwelt upon the immediate risks of nutritional and emotional deprivation rather than the long-standing damage inflicted by effectual torture or protracted or permanent parental absence. The emotional impact of school admission over a life course could be devastating. Second, surrender or rejection by parents

\footnotetext{
129 Balne, "Autobiography," 34-35.

${ }^{130}$ Erving Goffman, Stigma: Notes on the Management of Spoiled Identity (London, 1990), 46.
} 
meant that children sought alternative forms of comfort that were not necessarily overwritten by subsequent or adult affiliations. School staff or fellow pupils could substitute for parents, grandparents, or lateral kin when these did not prove adequate in childhood or subsequently. This is not to say that Poor Law institutions were anything other than a blunt and insufficiently regulated tool to address literal or effectual orphanhood, but it does imply that, for some children, institutions went some way to supply a deficiency of care and inspired appreciative sentiments in later life.

The intention of the 1834 law was to provide systematic relief in institutions that replicated welfare features across the country. Facilities for children in all locations were supposed to be ameliorated across the period, from dormitories within general workhouses to dedicated schools and cottage homes by 1913. What multiple local studies suggest, however, and what this research confirms in details such as Castle's illegitimate ejection from the workhouse and "Kate's" unauthorized chastisement of the boys in her ward, is that there were multiple Poor Laws in operation. This was the case despite the illusion of central oversight, fostered by policy lag and overwhelmingly by individuals' interpretation of their duties and experiences. Guardians, workhouse staff, and paupers all brought their preconceptions and personal mores to their specific institutions, with drastic consequences for the uniformity of practice and reception of the Poor Law. The diversity, waywardness, or downright neglect of policy implementation means that we need a new, affective chronology of the Poor Law, consciously diminishing the Dickensian stereotype and validating the diversity of other voices. 